\title{
A Study of Sediments and Radioactive Particles of the Yenisei River Using a Variety of Analytical Methods
}

\author{
A. Bolsunovsky', M. Melgunov ${ }^{2}$ \\ ${ }^{1}$ Institute of Biophysics SB Russian Academy of Sciences, Krasnoyarsk, Russia \\ ${ }^{2}$ Institute of Geology and Mineralogy SB Russian Academy of Sciences, Novosibirsk, Russia \\ Email: radecol@ibp.ru
}

Received April 2014

\begin{abstract}
The Yenisei River, one of the largest rivers in the world, is contaminated with artificial radionuclides released by a Russian nuclear facility producing weapon-grade plutonium, which has been in operation for many years. Examination of Yenisei River sediment samples revealed the presence of artificial radionuclides typical of radioactive discharge from the Mining-and-ChemicalCombine (MCC) nuclear facility: isotopes of europium $\left({ }^{152} \mathrm{Eu},{ }^{154} \mathrm{Eu}\right.$, and $\left.{ }^{155} \mathrm{Eu}\right)$, cesium $\left({ }^{137} \mathrm{Cs}\right.$ and $\left.{ }^{134} \mathrm{Cs}\right),{ }^{60} \mathrm{Co},{ }^{90} \mathrm{Sr}$, and transuranium elements. The MCC is also a source of radioactive particles in the Yenisei. New data on radionuclide concentrations in sediments and radioactive particles in the Yenisei River were obtained using a wide range of analytical methods. Sequential extraction performed on samples of sediment cores showed different degrees of potential environmental availability of artificial radionuclides and uranium. In a few samples, ${ }^{241} \mathrm{Am}$ was present in the unextractable form, which may be accounted for by the presence of microparticles of the reactor fuel. These microparticles were investigated using scanning electron microscopy, and their reactor origin was confirmed.
\end{abstract}

\section{Keywords}

Yenisei River Sediments, Artificial and Natural Radionuclides, Radioactive Particles, Sequential Extraction, Radionuclide Composition and Speciation, Analytical Methods

\section{Introduction}

The Yenisei is one of the world's largest rivers, over $3000 \mathrm{~km}$ long, flowing into the Kara Sea. The Mining-and-Chemical Combine (MCC) of Rosatom is located at Zheleznogorsk in the Krasnoyarsk Territory, on the bank of the Yenisei River, $60 \mathrm{~km}$ downstream of the city of Krasnoyarsk. The Combine has been producing weapons-grade plutonium in uranium-graphite reactors since 1958, when the first reactor was started up. The irradiated uranium is reprocessed at the radiochemical plant to separate uranium, plutonium, and fission products. The reactor plant houses three reactors. Two of them used the Yenisei water as coolant, i.e. the water was taken from the river to remove heat from the core, passed through the reactor fuel channels, and returned to the Yeni- 
sei. Both of these reactors were shut down in 1992, the third reactor was shut down in 2010. The radiochemical plant and other MCC facilities are still operating. Several scientific expeditions revealed that the Yenisei River floodplain is contaminated with artificial radionuclides, including plutonium isotopes, within $2000 \mathrm{~km}$ downstream of the MCC (Bolsunovsky et al., 2002; Klemt et al., 2002; Bolsunovsky \& Bondareva, 2007; Bolsunovsky et al., 2007; Bolsunovsky, 2010, 2011; Bolsunovsky \& Dementyev, 2010; Semizhon et al., 2010). Since 1995, researchers of the Institute of Biophysics (Krasnoyarsk) and the Institute of Geology and Mineralogy (Novosibirsk) have found radioactive particles in floodplain soils and sediments during their sampling campaigns at the Yenisei (Bolsunovsky \& Tcherkezian, 2001; Bolsunovsky, 2009; Chuguevskii et al., 2010). The source of these particles is the MCC, and they contain not only fission radionuclides (isotopes of cesium, plutonium, americium, curium, strontium) but also activation radionuclides (europium isotopes, ${ }^{60} \mathrm{Co}$ ). The MCC is also a source of uranium isotopes in the Yenisei. Thus, the Yenisei River basin is a unique environment for studying the mobility of both artificial radionuclides and uranium isotopes in the aquatic ecosystem. To effectively carry out such studies, researchers should employ a variety of methods, including nondestructive ones.

The purpose of this study was to obtain new data on concentrations of radionuclides in sediments and radioactive particles of the Yenisei River by using a wide range of analytical methods.

\section{Materials and Methods}

About 200 sediment cores were collected from the channel bed of the Yenisei River at different distances downstream of the MCC during 1997-2012 (Figure 1). For comparison purposes, we also collected sediment cores at a position upstream of the MCC, at the village of Esaulovo (45 km downstream of Krasnoyarsk) and at the city of Krasnoyarsk (Figure 1). The diameter of the sampler (made in Russia) was $11 \mathrm{~cm}$ and it was able to collect cores up to $180 \mathrm{~cm}$ long. Each sediment sample was a 3-cm thick layer, except for the top sediment layer, whose thickness ranged from 4 to $10 \mathrm{~cm}$, depending on the core moisture content. In the laboratory, some sediment samples were dried, but several samples were maintained wet and subjected to sequential extraction. The maximum number of layers for a core was 46, and the maximum length of the core was $147 \mathrm{~cm}$. We also studied radioactive particles extracted from sediments and floodplain soils of the Yenisei River.

Radionuclide measurements were performed using a wide range of instrumental methods: gamma-spectrometry with a "Canberra" spectrometer (U.S.), mass spectrometry with an "Agilent" spectrometer (U.S.), alpha-spectrometry with a EURISYS MEASURES spectrometer (France), and neutron activation analysis. Activity concentrations of radionuclides in sediment layers were decay corrected to the sample collection dates. Radioactive particles were additionally investigated using scanning electron microscopy (SEM) at the Institute of Geology and Mineralogy in Novosibirsk (Russia), with a LEO1430VP scanning electron microscope equipped with an "OXFORD" energy-dispersive spectrometer.

Binding of radionuclides to sediment samples was examined using sequential extraction technique proposed by Tessier and modified by Klemt and coauthors (Klemt et al., 2002; Semizhon et al., 2010). Six fractions were produced: I—Exchangeable Ions; II—Carbonates; III—Oxides and Hydroxides of Iron and Manganese; IVOrganic Matter; V-Amorphous silicates; VI—Residuals. It has generally been accepted that the less radionuclide activity is retained in the residual solids (Fraction VI), the more mobile this radionuclide is in the sediment.

Investigations and development of the X-ray fluorescence technique for determining the elemental composition of sediment were carried out on a VRA-20R Carl Zeiss fluorescent X-ray analyzer (Jena, Germany) at the Institute of Geology and Mineralogy in Novosibirsk (Russia). Results are reported in Table 1 (Bolsunovsky, 2010). As expected, river bottom sediments contained a large amount of $\mathrm{SiO}_{2}$ (56 - 68 mass\%). There was also a considerable percentage of $\mathrm{Al}_{2} \mathrm{O}_{3}$ (12.4 - 13.1 mass\%). The percentage of $\mathrm{Fe}_{2} \mathrm{O}_{3}$ varied from 4.6 to 5.3 mass\% and that of $\mathrm{MnO}$ constituted $0.1-0.2$ mass\%, as is typical of freshwater sediments. Percentages of Fe and $\mathrm{Mn}$ in sediment samples and their vertical distribution in sediments are commonly accepted indicators of the direction and features of geochemical processes. The samples also contained $\mathrm{MgO}, \mathrm{CaO}, \mathrm{Na}_{2} \mathrm{O}, \mathrm{K}_{2} \mathrm{O}$, and $\mathrm{TiO}_{2}$, which did not exceed 2 - 3 mass\%.

\section{Results}

\subsection{An Analytical Study of Concentrations of Radionuclides and Strength of Their Binding in Sediments of the Yenisei River}

Gamma-spectrometry measurements of sediment samples showed artificial radionuclides typical of the radioac- 


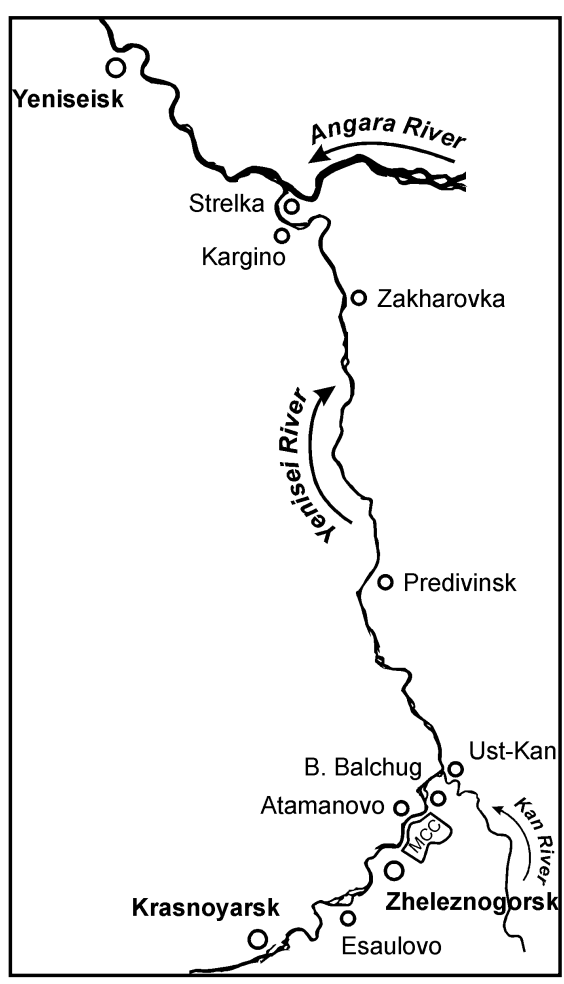

Figure 1. Map of the south of the Krasnoyarskii Krai (Russia), showing the MCC facility and settlements near where sediment samples were collected. Scale 1:2800000.

Table 1. Results of X-ray phase analysis of sediments, mass\% (Bolsunovsky, 2010).

\begin{tabular}{cccc}
\hline & Mean & Min & Max \\
\hline $\mathrm{SiO}_{2}$ & 63 & 56 & 68 \\
$\mathrm{TiO}_{2}$ & 0.76 & 0.7 & 0.8 \\
$\mathrm{Al}_{2} \mathrm{O}_{3}$ & 12.8 & 12.4 & 13.1 \\
$\mathrm{Fe}_{2} \mathrm{O}_{3}$ & 4.9 & 4.6 & 5.3 \\
$\mathrm{MnO}$ & 0.14 & 0.1 & 0.2 \\
$\mathrm{MgO}$ & 2.1 & 1.9 & 2.3 \\
$\mathrm{CaO}$ & 2.9 & 2.8 & 3.1 \\
$\mathrm{Na}_{2} \mathrm{O}$ & 2.5 & 2.0 & 2.9 \\
$\mathrm{~K}_{2} \mathrm{O}$ & 1.9 & 1.7 & 2.0 \\
\hline
\end{tabular}

tive discharge from the MCC to the Yenisei River: isotopes of europium $\left({ }^{152} \mathrm{Eu},{ }^{154} \mathrm{Eu}\right.$, and $\left.{ }^{155} \mathrm{Eu}\right)$, cesium $\left({ }^{137} \mathrm{Cs}\right.$ and $\left.{ }^{134} \mathrm{Cs}\right),{ }^{60} \mathrm{Co}$, and the transuranium element ${ }^{241} \mathrm{Am}$. The vertical distribution of radionuclides in the sediment cores is complex and there are several concentration minimums and maximums due to different amounts of radionuclides released by the MCC and due to variations in global fallout. Artificial radionuclides were detected in sediment layers both at the MCC and at considerable distances downstream of the nuclear facility. For the sediment core collected at site Kargino (320 km downstream of Krasnoyarsk), the maximum ${ }^{137} \mathrm{Cs}$ activity concentrations (up to $900 \mathrm{~Bq} \cdot \mathrm{kg}^{-1}$ ) were recorded in the middle and the lower parts, with relatively low concentrations at the surface. ${ }^{241} \mathrm{Am}$ (up to $10 \mathrm{~Bq} \cdot \mathrm{kg}^{-1}$ ) was also detected in the Kargino core (Figure 2). For the sediment cores collected near the MCC, maximum ${ }^{137} \mathrm{Cs}$ and ${ }^{241} \mathrm{Am}$ activities were several times higher: up to 4000 and 240 Bq/kg, respectively (Bolsunovsky et al., 2002, 2007; Bolsunovsky \& Bondareva, 2007; Bolsunovsky, 2010). The fact that some sediment layers contained high ${ }^{241} \mathrm{Am}$ concentrations could be indicative of high concentrations of other transuranium elements. Further analysis of the sediment layers that contained maximum levels of 


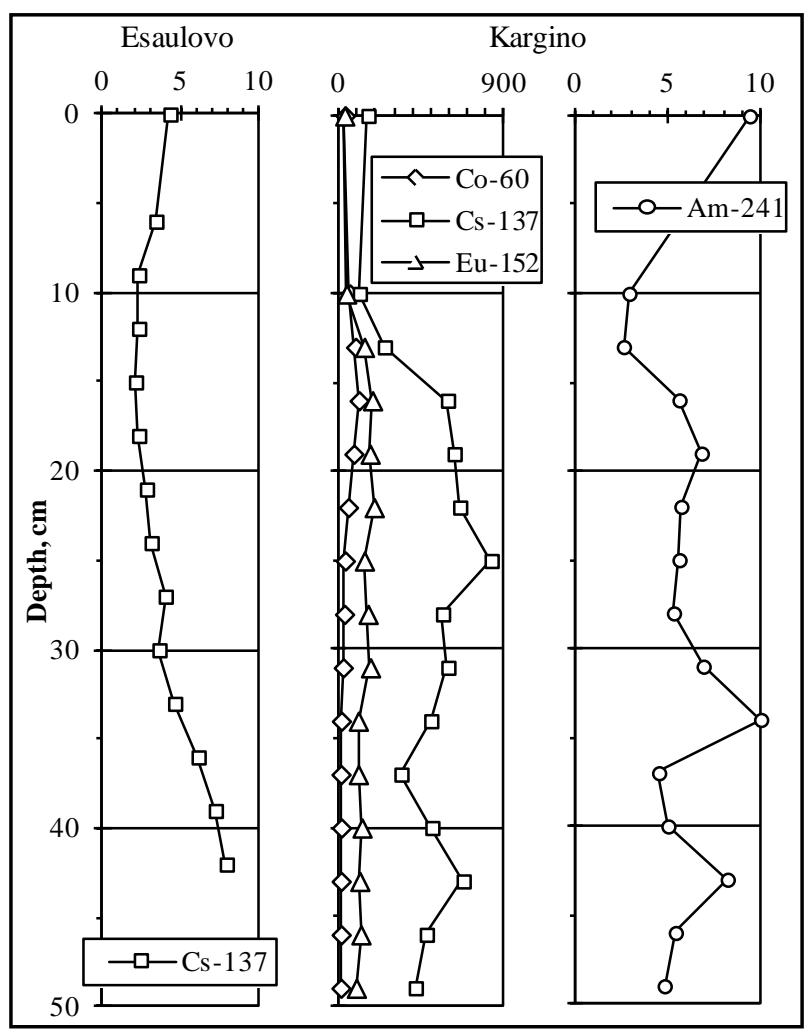

Figure 2. Representative vertical distribution profiles of radionuclides in channel bed sediments (Bq/kg dry mass) of the Yenisei River near the villages of Esaulovo (45 km downstream of Krasnoyarsk) and Kargino (320 km downstream of Krasnoyarsk). See Figure 1 for locations.

radionuclides, including ${ }^{241} \mathrm{Am}$, indicated that the Yenisei River sediment samples had local anomalous hotspots with high activity concentrations of transuranium elements, which were 100 times higher than their global fallout levels (Bolsunovsky et al., 2002, 2007; Bolsunovsky \& Bondareva, 2007; Bolsunovsky, 2010).

In layers of sediment cores collected at a position upstream of the MCC (the village of Esaulovo), the level of ${ }^{137} \mathrm{Cs}$ (up to $10 \mathrm{~Bq} / \mathrm{kg}$ dry mass) can be accepted as the background value of radioactive contamination of sediments in this section of the Yenisei, due to global fallouts of ${ }^{137} \mathrm{Cs}$ (Figure 2). In addition to artificial radionuclides, MCC effluents contain uranium isotopes. Our results suggest that upstream of the MCC, at the city of Krasnoyarsk and the village of Esaulovo, the average ${ }^{238} \mathrm{U}$ concentration in sediments is about $3.0 \mathrm{mg} / \mathrm{kg}$ dry mass. In sediments collected at the place where the MCC releases its radioactive water (at the villages of Atamanovo and B. Balchug), ${ }^{238} \mathrm{U}$ concentration is 1.5 times higher, reaching $4-5 \mathrm{mg} / \mathrm{kg}$. In some tributaries of the Yenisei River, close to Rosatom facilities, the highest ${ }^{238} \mathrm{U}$ concentrations in sediment layers amount to $6 \mathrm{mg} / \mathrm{kg}$.

Sequential extraction techniques are the most common method of studying radionuclide speciation in soils and sediments. Sequential extraction performed on samples of the upper layers of the sediment core collected near the MCC showed (Figure 3) that the amounts of extracted ${ }^{90} \mathrm{Sr},{ }^{152} \mathrm{Eu}$, and ${ }^{241} \mathrm{Am}$ were the largest (reaching $80 \%$ of initial activity), then followed ${ }^{60} \mathrm{Co}(30 \%),{ }^{238,239,240} \mathrm{Pu}(15 \%-30 \%)$, and, last, ${ }^{137} \mathrm{Cs}(5 \%-15 \%)$. The distribution of ${ }^{238} \mathrm{U}$ among chemical fractions of sediments was similar to that of ${ }^{60} \mathrm{Co}$. The largest amounts of the radionuclides were extracted from such fractions as organic matter (Fraction IV) and oxides and hydroxides of iron and manganese (Fraction III). In a few samples, almost all ${ }^{241} \mathrm{Am}$ was present in the unextractable form (Fraction VI), which may be accounted for by the presence of microparticles of the reactor fuel. Assessment of potential environmental availability of artificial radionuclides in the analyzed sediments from the Yenisei River was based on the data for the first four fractions (Exchangeable Ions, Carbonates, Oxides and Hydroxides of Iron and Manganese, and Organic Matter) of sequential extraction. Based on our results (Figure 3), we arranged radionuclides in the following sequence, showing their relative mobility in the upper layers of the cores (Bolsu- 


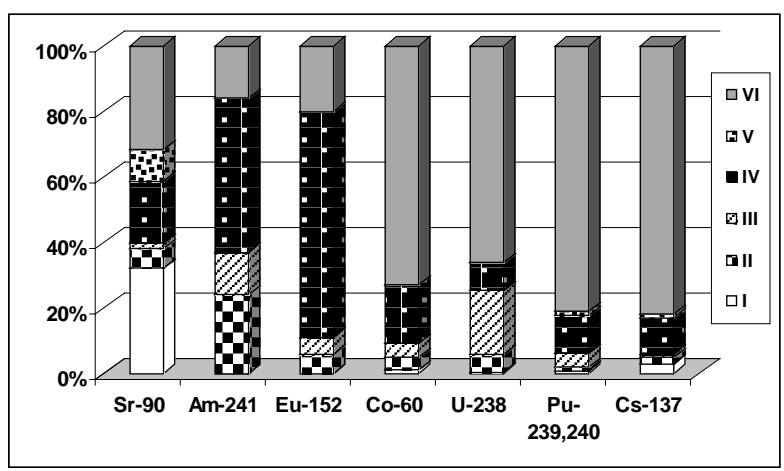

Figure 3. Typical distribution of radionuclide activities among chemical fractions of the upper layers of the sediment collected near the MCC (Bolsunovsky, 2011). Fractions: I-Exchangeable Ions; II-Carbonates; III-Oxides and Hydroxides of Iron and Manganese; IV-Organic Matter; V-Amorphous silicates; VI-Residuals.

novsky, 2010, 2011):

$$
{ }^{90} \mathrm{Sr} \approx \approx^{241} \mathrm{Am} \approx \approx^{152} \mathrm{Eu}>>^{60} \mathrm{Co} \approx^{238} \mathrm{U}>^{239 / 240} \mathrm{Pu} \geq^{137} \mathrm{Cs} .
$$

\subsection{An Analytical Study of Radioactive Particles of the Yenisei River}

As noted above, since 1995, researchers of the Institute of Biophysics (Krasnoyarsk) and the Institute of Geology and Mineralogy (Novosibirsk) have found a number of radioactive particles in floodplain soils and sediments during their sampling campaigns at the Yenisei (Bolsunovsky, Tcherkezian, 2001; Bolsunovsky, 2009; Chuguevskii et al., 2010). Analytical studies showed that these particles contained not only fission radionuclides (isotopes of cesium, plutonium, americium, curium, strontium) but also activation radionuclides (europium isotopes, ${ }^{60} \mathrm{Co}$ ). The highest ${ }^{137} \mathrm{Cs}$ activity in the particles reached $30 \mathrm{MBq} /$ particle (Bolsunovsky \& Tcherkezian, 2001; Bolsunovsky, 2009). Investigations of radioactive particles performed in Russian and Norwegian laboratories proved their reactor origin. Based on comparative analysis of ${ }^{137} \mathrm{Cs} /{ }^{134} \mathrm{Cs}$ ratios, all the particles can be divided into three major groups, suggesting that over the 50-year period of the MCC operation, there had been three emergency situations at the MCC reactors, with nuclear fuel microparticles released into the Yenisei. Investigations carried out in Novosibirsk and Krasnoyarsk institutes showed that alluvial soils and sediments of the Yenisei floodplain downstream the MCC are contaminated by radioactive particles of various types and activities (Bolsunovsky, 2009; Chuguevskii et al., 2010). All the particles can be divided into two classes of activity: 1) radioactive particles with the activity of ${ }^{137} \mathrm{Cs}$ (or another radionuclide) from several $\mathrm{kBq} / \mathrm{particle}$ to several tens of $\mathrm{MBq} /$ particle, and the number of such particles in the Yenisei floodplain is roughly estimated as 100 particles $/ \mathrm{km}^{2}$; 2) radioactive microparticles with the activity of ${ }^{137} \mathrm{Cs}$ (or another radionuclide) from several $\mathrm{Bq} / \mathrm{particle}$ to several hundred Bq/particle. These microparticles were investigated and their reactor origin was confirmed. As an example, Table 2 gives results of scanning electron microscopy of one particle. The spatial distribution of some elements over the scanned surface of the isolated particle region obtained by energy-dispersive analysis shows that at points 1 - 3, the major element of the particle is uranium, while at points 4 and 5 , carbon is the main element of the particle matrix. These data are indicative of the uranium-graphite (i.e. nuclear fuel) origin of this particle (Chuguevskii et al., 2010).

\section{Conclusion}

By using modern spectrometric methods, we determined a great number of artificial and natural radionuclides in sediments and radioactive particles of the Yenisei River. Scanning electron microscopy of microparticles proved their reactor origin. Binding of radionuclides to sediment samples was examined using sequential extraction technique. Based on results obtained, we arranged artificial radionuclides and uranium in the sequence showing their relative mobility in the layers of the sediment core. 
Table 2. Elemental composition (\%) of hot particles (Chuguevskii et al., 2010).

\begin{tabular}{cccccc}
\hline \multirow{2}{*}{$\begin{array}{c}\text { Element, } \\
\%\end{array}$} & 1 & 2 & 3 & 4 & 5 \\
\cline { 2 - 6 } C & 5.2 & 7.4 & 7.7 & 65.3 & 88.2 \\
$\mathrm{O}$ & 19.6 & 17.5 & 22.4 & 25.3 & 11.4 \\
$\mathrm{Al}$ & & & & 1.5 & \\
$\mathrm{Si}$ & & 1.1 & 0.6 & 0.4 \\
$\mathrm{P}$ & & & 0.5 & \\
$\mathrm{~S}$ & & & 0.7 & \\
$\mathrm{Ca}$ & & & 0.7 & \\
$\mathrm{Fe}$ & & & & 1.7 & \\
$\mathrm{U}$ & 75.2 & 75.1 & 68.8 & 3.7 & \\
Total, \% & 100 & 100 & 100 & 100 & 100 \\
\hline
\end{tabular}

The study was partly supported by Russian Foundation for Basic Research (RFBR) Grant No 12-05-00078 and IAEA Research Contract No 17941.

\section{References}

Bolsunovsky, A. (2009). Hot Particles in the Floodplain of the Yenisei River. In Radioactive Particles in the Environment. Springer, 111-121. http://dx.doi.org/10.1007/978-90-481-2949-2_6

Bolsunovsky, A. (2010). Artificial Radionuclides in Sediment of the Yenisei River. Chemistry and Ecology, 26, 401-409. http://dx.doi.org/10.1080/02757540.2010.504668

Bolsunovsky, A. (2011). Radionuclide Speciation in Sediments of the Yenisei River. Radioprotection, 46, S195-S198. http://dx.doi.org/10.1051/radiopro/20116457s

Bolsunovsky, A., \& Bondareva, L. (2007). Actinides and Other Radionuclides in Sediments and Submerged Plants of the Yenisei River. Journal of Alloys and Compounds, 444-445, 495-499. http://dx.doi.org/10.1016/j.jallcom.2007.01.146

Bolsunovsky, A., \& Dementyev, D. (2010). Sediments of the Yenisei River: Monitoring of Radionuclide Levels and Estimation of Sedimentation Rates. IAHS Publ., No337, 143-148.

Bolsunovsky, A. Ya., \& Tcherkezian, V. O. (2001). Hot Particles of the Yenisei River Flood Plain, Russia. Journal of Environmental Radioactivity, 57, 167-174. http://dx.doi.org/10.1016/S0265-931X(01)00021-2

Bolsunovsky, A., Ermakov, A., \& Sobolev, A. (2007). New Data on Transuranium Elements in the Ecosystem of the Yenisei River Floodplain. Radiochimica Acta, 95, 547-552. http://dx.doi.org/10.1524/ract.2007.95.9.547

Bolsunovsky, A. Ya., Ermakov, A. I., Myasoedov, B. F., Novikov, A. P., \& Sobolev, A. I. (2002). New Data on the Content of Transuranic Elements in Bottom Sediments of the Yenisei River. Transactions Dokl Akad Nauk, 387, $233-236$.

Chuguevskii, A. V., Sukhorukov, F. V., Melgunov, M. S., Makarova, I. V., \& Titov, A. T. (2010). "Hot” Particles of the Yenisei River: Radioisotope Composition, Structure, and Behavior in Natural Conditions. Doklady Earth Sciences, 430, 51-53. http://dx.doi.org/10.1134/S1028334X10010113

Klemt, E., Spasova, Y., Zibold, G., \& Bolsunovsky, A. (2002). Deposition of Artificial Radionuclides in Sediments of the River Yenisei. In P. Strand, T. Jolle, \& A. Sand (Eds.), Environmental Radioactivity in the Arctic \& Antarctic (pp. 67-70). Norway: Norwegian Radiation Protection Authority.

Semizhon, T., Röllin, S., Spasova, Y., \& Klemt, E. (2010). Transport and Distribution of Artificial Gamma-Emitting Radionuclides in the River Yenisei and Its Sediment. Journal of Environmental Radioactivity, 101, 385-402.

http://dx.doi.org/10.1016/j.jenvrad.2010.02.012 